\title{
Conflict Resolution and Peacebuilding: The Long-Lasting Trauma of Myanmar
}

\author{
Hsu Thiri Zaw \\ School of Journalism and Information Communication, Huazhong University of Science and Technology, Wuhan, China \\ Email: hsuthirizaw@yahoo.com
}

How to cite this paper: Zaw, H. T. (2018) Conflict Resolution and Peacebuilding: The Long-Lasting Trauma of Myanmar. $A d$ vances in Journalism and Communication, 6, 121-138. https://doi.org/10.4236/ajc.2018.64010

Received: November 20, 2018 Accepted: December 10, 2018 Published: December 13, 2018

Copyright (c) 2018 by author and Scientific Research Publishing Inc. This work is licensed under the Creative Commons Attribution International License (CC BY 4.0).

http://creativecommons.org/licenses/by/4.0/ (c) (i) Open Access

\begin{abstract}
Myanmar has been experiencing the ethnic conflicts for 70 years since after its independence in 1948. Based on the lack of trust and mutual understanding among the government, majority ethnic Burmese group and other minority ethnic groups, the term "Burmanization" becomes popular due to the discriminations and suppressions on the ethnic people in many sectors. This article analyzes the nature of ethnic conflicts in Myanmar and the consequences and situations from the independence time to the current time under democratic government. The author presents this article as a type of analysis paper which points out some reasons why Myanmar's peace process is never ending throughout the history. The study attempts to show detailed information about how Myanmar governments tried to shape conflict resolution and peace building in the country and why it is still traumatic in the country. Moreover, this study also speaks more about some solutions for peacebuilding process from different dimensions and communication.
\end{abstract}

\section{Keywords}

Ethnicity, Ethnic Conflicts, Conflict Resolution, Peacebuilding, Myanmar, Communication

\section{Introduction}

The 1991 Nobel Peace Prize winner Aung San Suu Kyi praised cultural diversity as follows: "It is precisely because of the cultural diversity of the world that it is necessary for different nations and people to agree on those basic human values which will act as a unifying factor." It can be assumed that cultural diversity is a kind of blessing for its people in the country. Myanmar is highly ethnically diverse, with 135 ethnicities officially recognised by the government. The Burman (or "Bamar") ethnic group is the majority, with perhaps two thirds of the popu- 
lation, while ethnic communities - the major being the Shan, Karen, Rakhine, Mon, Kachin, Chin and Kayah-are thought to collectively account for perhaps one third of the population. In addition, communities of Chinese and Indian origin account for perhaps 4 percent of the population (Smith, 2007). However, all these population figures are uncertain and contested, since no ethnic census has been conducted in decades. It is also important to note that throughout Myanmar's history, there has been cultural and ethnic interchange, and that ethnic populations should not be interpreted as unchangeable and isolated from each other (Tucker, 2001).

Moreover, the demography of Myanmar is quite complicated based on cultural diversity and cross-breeding. As the people spread into different regions throughout the country, their language, dressing style, customs, beliefs, ideas and tradition have been totally different. Instead of the diverse culture and tradition, tensions, between and within ethnic groups based on discrimination ethnic cultures and traditions and also religions, have been painted throughout the history (Taylor, 2009). Under the British colonial time in 1886, Myanmar (Burma) was an Indian province and it was not a unified nation state. One year before the independence, in 1947, General Aung San who was the leader of Myanmar Independence Army and national hero, completed negotiation a good plan for independence at its time with the British colonial government and tried to persuade ethnic minority groups to enter into the umbrella of Union of Myanmar. He established the Panglong Agreement in February, 1947 that included his government promises to ethnic people for their rights (Smith \& Ekeh, 2007, Minorities in Burma).

Due to the lack of the ethnic rights, Myanmar has been at war with itself since its independence in 1948, a struggle mainly playing out in the country's ethnic borderlands. Throughout the history, those regions have never been fully controlled by the State. In the British colonial time, those regions were controlled separately from central Burma as Frontier Areas and a kind of local autonomy. At the Panglong Conference in 1947 which was the key conference among ethnic groups before Myanmar independence in the history, Shan, Kachin and Chin representatives from Frontier Areas agreed to the formation of a Union of Burma in return for full autonomy in the governance of their areas and equal share of revenues. Nevertheless, since that time, the Karen which is one of the largest minorities did not participate in these historical negotiations, sending only an observer team and it also got strong criticism among other ethnic groups. According to many divides, civil war broke out since after independence in 1948 and those ethnic conflicts are still going on for 70 years in the country (Smith, 2015).

\section{Literature Review}

\subsection{Ethnicity and Ethnic Conflicts}

According to Horowitz (1985), the term "ethnicity" can be defined as a sense of collective belonging which could be based on common descent, language, histo- 
ry, culture, race or religion. An ethnic group may do without a state of its own; a nation implies bringing ethnicity and statehood together (Horowitz, 1985). Gellener (1983) stated that the political and the national unit should be congruent and that kind of congruence may be satisfied in a federal arrangement, or may head for nothing short of sovereignty (Gellener, 1983).

In human history, it is clearly seen that conflict is mentioned with religions, gender and ethnic issues. Horowitz (1985) argued again that "the field of ethnic conflict has been a backwater of the social sciences" (Horowitz, 1985). Some important social science arguments had emerged earlier, especially on the relationship between ethnicity and nation building, ethnicity and modernity, ethnicity and consociation democracy and migration and ethnic conflict (Lijphart, 1969). Ethnic groups in conflict covered a wide array of topics under the umbrella of ethnicity becoming thereby the founding text of the field (Varshney, 2009). In research field, ethnicity has become a growth industry, straddling a variety of disciplines, topics and methods, and attracting a large number of scholars.

In previous times, scholars often used to leave theory building to a link, or affinity, between structural conditions and the rise of ethnic conflict. An ethnic conflict can be defined as a conflict between two or more contending ethnic groups. While the source of the conflict may be political, social, economic or religious, the individuals in conflict must expressly fight for their ethnic group's position within society. Ethnic conflict does not always have to be violent. It can come as an everyday feature of plural democracies in a multi-ethnic society where freedom of speech is protected. In healthy multi-ethnic democracies, these conflicts are usually institutionalized and "channeled through parliaments, assemblies and bureaucracies or through non-violent demonstrations and strikes" (Horowitz, 1985).

It is questionable that after the lingering ethnic conflicts, peace can surely be developed without reconciling the actors and the victims (Power, 2002). Therefore, it is necessary to know about the issues surrounding the nature of "victims" in conflict and the role of "justice" in peace process, and also the characteristics of support in obtaining reconciliation and justice which already have been the key player of peace process in lingering ethnopolitical conflicts.

It is necessary that political institutions distinct from those that are suitable for ethnically undivided societies in ethnic pluralism. Lijphart (1969) claimed that each ethnic group's political and cultural affairs are left to its elite, and inter- ethnic compromises are made only at the elite level (Lijphart, 1969). On the other hand, Varshney (2009) argues that local variation in conflict is best explained by whether local civic organizations, including political parties, exist and whether they integrate ethnic communities or segregate them (Varshney, 2009).

In an ethnically plural society, where freedom of expression is not curtailed, some conflict on identity-based cleavages normally might break out. However, comparing with an authoritarian political system, a democratic political system can simply have a more open expression of such conflicts (Varshney, 2009). On 
the other hand, it can also be seen that conflicts are a much more regular feature of pluralistic democracies for struggling their rights and freedom such as: which language should be used in schools and employment, whether migrant ethnic groups should be allowed entry into the country and/or given restricted rights, whether different groups should be under one civil law for marriages, divorce, and property inheritance, or multiple family laws should be derived from the diverse religious or customary codes, whether religious dress can be allowed in public spaces, whether some groups should be given the benefits of affirmative action, how and to what extent, whether the allocation of public resources favors some ethnic groups more than others.

\subsection{Conflict Resolution and Peacebuilding}

Galtung (1996) mentioned that there are three dimensions in conflict like a triangle which are 1) assumptions and attitudes, 2) behavior and 3) contradictions (in actions). Conflicts break out when there are some inversions in the aim of one side and they are different. One more noticeable thing is that such kind of inversion and differences can lead to the violence. Therefore, it can be strongly said that the three dimensions of the conflict are like the lines in triangle which reflect the nature of human relationship (Galtung, 1996).

However, Mitchell (1981) argued that conflict is organized based on situation, attitude and behavior axes. According to Peleg's explanation on those three dimensions, situation axis stands for the initial interest that motivate the other ones to encounter while the attitude axis which is the psychological factor works for stigma and prejudice from both parties. The last axis, behavior axis is the factors which measure how the parties act toward each other based on their situations and attitudes (Mitchell, 1981).

The term "Peace" is always connected with the war and conflict. According to Barash (2000), no one can try for attaining peace fully, however, someone can approach to peace (Barash, 2000). According to the political science, hard power and soft power are mentioned showing the differences such as economic, military, cultural and political. Among them, peace depends on the soft form of power (Galtung, 2010). Galtung (1996) also pointed out that peace has connection with war. He defined "negative peace" as "absence of war" or "ceasefire" while "positive peace" is regarded as conditions which lead to "non-violent" ways in the society concerning conflict (Galtung, 1996, Peace by peaceful means: Peace and conflict, development and civilization) Concerning peace, the concept-peacebuilding is defined as the way to generate and approach the conflict transformation into the long-term harmonious relationships in the society (Lederach, 1995). Moreover, Galtung (1998) regarded peacebuilding as the structure of eliminating the reasons that can cause the wars and conflicts and on the other hand, supporting the foundation to peace (Galtung, 1998).

According to Bonta (1996), the conflict resolution means that "the settlement or avoidance of disputes between individuals or groups of people through solutions that refrain from violence" (Bonta, 1996). Apart from Bonta's definition 
about conflict resolution, Spiller (2002) mentioned about it that the answer of conflict resolution will vary according to the needs of the involving parties both tangible and intangible ones (Spiller, 2002).

When it says about conflict resolution, it is organized with four principles which are arbitration, litigation, negotiation and mediation which the first two are formal functions with court room proceeding while the next two are quite informal and third party may or may not necessary to participate in the procedure. Nevertheless, among those functions, negotiation and mediation are the popular principle which every peacemaker is applying these days (Aslam, 2014).

When it says about a successful conflict resolution, the process must be based on the truthful and honest interactions between players. In general, conflicts always break out due to the lack of supply of the basic needs for parties and those kind of lacking turns into grievances and hatred and later, those negative feelings lead to conflicts (Peleg, 1999). Galtung (2010) expressed peace as the equal way of "conciliation" when it says about conflict resolution. Moreover, he pointed out that conciliation is regarded for violence while mediation is for conflict because conciliation can cure the trauma and create a future plan for peace (Galtung, 2010).

\section{Analysis Report}

\subsection{Myanmar with Its Ethnic Conflict during Post-Independence Era (from 1948-1962)}

Before Myanmar's independence, General Aung San who was the national hero of Myanmar and his cabinet members tried to hold Panglong conference in 1947 which is the agreement that non-Burmese ethnic groups such as Chin, Kachin, Shan and so on promised that they also would like to get independence together with Burmese and join the Burmese in founding the Union comprised with all ethnic people. On the other hand, the Panglong agreement also promised that the ethnic people could get the rights to exercise the administration, judiciary and legislative powers in their autonomous ethnic regions and maintain and protect their own ethnic languages, culture and religion (Silverstein, 1981).

After the national hero, General Aung San was assassinated on $19^{\text {th }}$ July, 1947, $\mathrm{U} \mathrm{Nu}$ became the leader of the government. During his regime, it could be said that the governing policies of the government went backward to the old kingdom of Burma (Sakhong, 2012). Firstly, the leader U Nu commanded U Chan Htun to outline the Union Constitution drawn by General Aung San and that $U$ Chan Htun's version of Constitution was submitted to the Constituent Assembly of the interim government of Burma in September, 1947. That constitution changed totally the fate of the ethnic people of Burma because it became a non-genuine federal union under that new drawn constitution. U Chan Htun himself admitted that Burma is just a unitary country though it says federal state in theoretical way (Tinker, 1967).

Though the leader, General Aung San's policy was based on "pluralism" and 
"policy of unity in diversity" which all ethnic groups from different religion with various cultures and tradition could live together peacefully, $\mathrm{U} \mathrm{Nu}$ applied culture and religion as the fundamental value of nation-building process. In 1961, he announced that Buddhism as the state religion of the Burma. Such announcement was the violation of the agreements from Panglong conference which General Aung San and ethnic leaders agreed for founding a federal state based on unity and equality (Sakhong, 2012).

Such violation of Panglong agreement and equality was protested in two ways by ethnic groups. The first protest was by Kachin Independence Army's rebellion movement to the central government and its decision on announcing Buddhism as state religion. Graver mentioned that those Kachin Christians saw that announcement as the prior act of Burmanization in the country by the government (Gravers, 1993). Moreover, Chin rebellion led by HrangNawl started rebellion movement in 1964 for protesting the government's announcement about state religion.

There were some other moderate groups who demanded for the solution according to constitution and the leader of the groups was Sao ShweThaike, an influential Shan Sawbwa and also the first president of Burma since after independence. He strongly opposed to that announcement although he believed deeply in Buddhism because he assumed that this is the violation of the Panglong agreement (Sakhong, 2010). Therefore, Sao ShweThaike called not only the leaders of ethnic groups such as Chin, Kachin and Shan which were the members of the Supreme Council of United Hills People (SCOUHP) but also the leaders of other ethnic groups such as Karen, Kayah, Mon and Rakhine to Taunggyi for making discussion those problem and later, that conference has been known as "1961 Taunggyi Conference". In the conference, the participants mostly discussed about the amendment of Union Constitution according to the draft by General Aung San (Sakhong, 2012).

According to Silverstein (1993), General Aung San agreed to build a Union under the regulations which protect the rights of ethnic people. General Aung San drafted the constitution based on the forming of Union State comprised with ethnic national states such as Chin, Kachin, Shan, Karen, Mon, Rekhine, Burma and so on (Silverstein, 1993). Though the first draft constitution of Myanmar by General Aung San was based on federalism, U Chan Htun's version of the constitution deviated the main concept of the federalism. Therefore, the leaders who attended in 1961 Taunggyi conference demanded for the genuine federalism and federal union which are composed with ethnic states and self-determination (Sakhong, 2010). As the demand of the 1961 Taunggyi Conference were strong enough, $\mathrm{U} \mathrm{Nu}$ had to initiate the "Federal Seminar" with all political leaders and legal experts from both majority Burmese groups and ethnic minority groups with the intention to discuss the issues of federalism and the problems which minorities are facing to get the best solution from every detailed point (Silverstein, 1981).

They intended to open the meeting on $24^{\text {th }}$ February, 1962 in Yangon exactly 
during the time of parliamentary meeting session. However, the seminar unfortunately concluded even before it was started because the military led by General Ne Win took the state power under the name of "Revolutionary Council," Furthermore, General Ne Win arrested all the ethnic participants who participated in Federal Seminar and cabinet members who were legally and constitutionally elected on $2^{\text {nd }}$ March, 1962. Since that time, the parliament disappeared in political stage and also the constitution suspended and moreover, the government stopped all the discussion on federal issues and ethnic minority rights (Sakhong, 2012). In addition, the government could not provide the norms to form the Union state based on the concepts of multi-ethnic, diversity in religions and cultural plural society under the military's leadership.

\subsection{Myanmar with Its Ethnic Conflict during Socialist Era (from 1962-1988)}

After 1962, the Burmese military led by General Nay Win took the political power in the country and established the revolutionary council. The council and the government followed the socialist ideologies called the "Burmese Way to Socialism" (Schein, 2013). Under the socialism, the government structure intruded and invaded into all sectors of society. Federalism, autonomy and administrative independence were gotten rid from the government structure. Moreover, education, music and dance which are the fundamental keys for ethnic culture and tradition were suppressed by the government and the government controlled the censorship on publications and language usages. On the other hand, the Socialist council which was also the government at that time suppressed ethnic rights and privileges (Schein, 2013). As the government was not based on democracy and liberalism, the ethnic council which was established since 1947 was abolished and substituted with directly assigned administrations. According to the Taylor (2009), the Revolutionary Council's objectives were mainly for getting rid of ethnicity as a constitutional issue and substitute that terms with "regional development and cultural diversity" which are more controllable ones in governing structure (Taylor, 2009).

1962 Printers and Publishers Registration Law and 1965 Censor Law were the key point to suppress on ethnic rights because those two laws blocked for the publication of ethnic languages especially publishing the curriculums and teaching materials for secular schools and Sunday schools (Sakhong, 2012). Therefore, the non-Burmese ethnic groups who believe in Christianity faced the problems in promoting their languages and cultures under the military regime. With the repression on the ethnic culture, tradition, language and religion, the tasks for preserving, protecting and promoting ethnic culture and tradition became the most important responsibility for ethnic people because freedom on cultures, languages and religions are fundamental rights for citizens.

In the political sector, the Revolutionary Council established the second constitution of Myanmar which was created by the council. The government was the central government which controlled all administrative functions by the military 
down to the village level (Taylor, 2009). According to constitution, the Socialist government's leader, General Nay Win, announced Burmese language as the official language of the Union of Burma though ethnic languages were applied for communicating between the central Burmese government and ethnic states. However, there were no organization of institutions for encouraging the preserving and protecting procedures of ethnic languages (Sakhong, 2012). In the Parliament (Pyithu Hluttaw), only members of military's Burma Socialist Program Party (BSPP) had chance to participate in legislative structure and also those members were selected by the party. The country's territories were divided into 7 regions and 7 states and mostly, the states were named for ethnic groups' name. However, it was not for ethnic placing, but just for administrative organization. According to Silverstein (1977), the Socialist government targeted the direct control in the nation applying the strong and center-controlled administrative structure (Silverstein, 1977).

During the Socialist government regime, ethnic minorities of Myanmar had to struggle quite much on human rights violations and suppressions on ethnic culture and tradition (Schein, 2013). Moreover, the participation of the ethnic minorities in the governmental functions was so low due to the domination by the government and restriction on the ethnic minorities' rights. As the central government took the top power of the country in Burmese hands, ethnic political parties demanded for the decentralized federal governing structure comprised with ethnic autonomous states in the country. However, they did not succeed in implementing the calling for the ethnic rights (Chrisitina, 2000). In addition, the socialist government regarded the term "federalism" as the source of the separation and the nation's disintegration. On the other hand, the ethnic people who have been longing for federalism and autonomous regions organized nationalist armies within their ethnic groups and started underground movement. Therefore, the military operated brutal campaigns in ethnic areas and as a result, the grudges and hatred of ethnic people on central government increased a lot (Chrisitina, 2000).

Moreover, since after 1962, Kachin students and other students started insurgencies due to the protection of their culture and religion and such insurgencies had become widespread (Taylor, 2017). Since the time when new constitution was declared in 1974, General Nay Win became U Nay Win took the state power as the President of the Socialist Republic of the Union of Burma. On the other hand, all ethnic groups had insurgent groups for protecting their ethnic rights and equality. Karen National Union (KNU), Kachin Independent Organization (KIO) and Shan State Army (SSA), New Mon State Party (NMSP), Karenni National Progressive Party (KNPP), Arakan Liberation Party (ALP) and Chin Democracy Party were significant and large groups among all ethnic insurgent groups (Sakhong, 2012).

General Nay Win who was the leader of the Socialist government used "four-cut" strategy in the ethnic minority regions for "national language policy". For that plan, military was deployed in ethnic regions with the motto of "one 
voice, one blood and one nation" in 1966 which aimed to cut the food supply to the insurgents, to cut protection money from villagers to the insurgents, to cut contacts (information and intelligence between people and the insurgents and to make the people involving in fighting. Moreover, the four cut strategy was obviously linked to the national language policy to against ethnic nationalities.

In spite of succeeding in establishing four-cut strategy in ethnic regions by the government, the ethnic insurgent groups could control the specific ethnic regions and their troops were even capable to fight with military in guerrilla warfare. Moreover, Smith (2007) pointed out that the ethnic insurgent groups' power spread to the entire eastern mountain areas and border of Myanmar from south of Tanintharyi region to the north Kachin state. Among the insurgent groups, KNU, KIO and SSA were the strongest groups with over 5000 troops and they even had fights with military through trading and border problems (Smith, 2007). Due to the mismanagement of the government upon socialist ideology, the people relied on the black market for most of the goods which came from neighboring countries because the country's economy which were based on closed market economy was not stable. As the result, the centers of the black market were mainly in the ethnic insurgents controlled regions so the government established the next four cut strategy which was to cut off the financial resources to ethnic armed groups which influenced the black market. Therefore, he declared the demonetization of the country's three highest banknotes with the intention of getting rid of insurgents and black marketers (Lintner, 1999). However, only citizens suffered the trauma of demonetization by the government at that time.

The Socialist government after 1962 used every single political way to build the army state with the term "one voice, one blood, one nation" and on the other hand, it also meant that building ethnically homogenous unitary state with the ideology of "one religion, one language, one ethnicity." Under the building of such ethnically homogenous state, the fundamental rights of every ethnic group, equality and self-determination of ethnic people were all destroyed (Sakhong, 2012). In 1988, there was the biggest protest throughout Myanmar's history which were against the government's system and demanded for the democracy.

\subsection{Myanmar with Its Ethnic Conflict during Military Regime (from 1989-2010)}

After 1988 uprising movement, the military seized the state power and formed the council known as "State Law and Order Restoration Council" in 1989 under the control of General Saw Maung. The government changed the country name "Burma" which was formerly known to "Myanmar." SLORC eliminated the 1974 constitution and promise to hold an election in 1990. In 1990 election, the opposition party, National League for Democracy (NLD) won 392 seats out of 485 seats due to the DawAung San Suu Kyi who is the daughter of General Aung San, the national hero for independence in Myanmar and also allied ethnic parties. However, the military government didn't agree to hand over the state power 
to the winning party because the government gave the reason that the two influential leaders from NLD were arrested since $19^{\text {th }}$ July, 1989 (Sakhong, 2012).

Unless the handing the state power to winning party, the military government claimed that the constitution should be drafted first. Therefore, SLORC held a national convention in 1993 and the national convention was finished on $3^{\text {rd }}$ September, 2007 after 14 years. Later, the military government changed its name from SLORC to "State Peace and Development Council (SPDC)". The military government held National Referendum to adopt the constitution in May, 2008.

During the SPDC government regime, the government always tried to control in the ethnic conflict zones under the name of "ceasefire agreement." Therefore, the government initiated the ethnic ceasefire policy in 1989 and later the year, it covered the majority ethnic armed forces in the country (Nederland, 2010). By making the ceasefire agreement with the government, most of the ethnic groups were recognized as semi-autonomous or "sub-contractor" of the region and mostly, they were allowed to start up the new business in the country. Such kind of situation became the good opportunities for ethnic groups and their people who had been living in low-level standard for many years (Sakhong, 2010).

Many reports mentioned that SPDC government established ceasefire agreement with armed ethnic groups and the project was led by Military Intelligence (MI) and its leader General KhinNyunt. The government discussed with 40 groups prior to 2010 but there was no official ceasefire agreement between government and ceasefire ethnic armed groups except the case of Kachin Independence Organization (KIO). The government and KIO kept the formal ceasefire agreement as a secret even for many decades after it was signed in 1994. As the ceasefire agreement was not written and registered formally, the military government had to reward them with business opportunities such as jade mines, mineral extraction and logging for restriction on arms expansion and recruiting because such kind of unwritten ceasefire agreement allowed the ethnic armed groups to retain the weapons and some influence in territories. Vice versa, ethnic armed groups could not discuss about political settlements with the government. During the military regime, Karen National Union (KNU) and Restoration Council for Shan State (RCSS) were the only ethnic armed groups which refused the ceasefire agreement and continued the fighting (Oo, 2014).

Meanwhile, some ethnic armed organizations changed into a new path to the alternative political system which is agreeing to form the Border Guard Forces (BGF) under the direct control of the military. Totally, five ethnic groups and four local militia chose the new path of forming BGF while eight ethnic groups refused the offer of the government. For forming local militia, there are over 50 groups under the military regional commands. However, the military government was criticized by the opposition groups for the misspending the power of ethnic people in politics (Nederland, 2010).

With the downfall of MI in 2005, the Karenni National Progressive Party (KNPP) started breaking out the ceasefire agreement and continued fights, 
however, all other ceasefire groups still followed the deal of ceasefire agreement with the government except small number of violations. The ceasefire ethnic armed groups also worried about the retaining of ceasefire with the government after the downfall of MI and its leader General KhinNyunt in October, 2015 because MI was a well-developed communication tool between government and ethnic armed organizations during military regime. Though the government substituted the place with some personnels from Military Security Affairs (MSA), it was so difficult to restore the trust and mutual understanding between government and ethnic armed organizations again (Oo, 2014).

During 2009, conflicts between the military and KNU started again and KNU was the target of military counter-insurgency operations at those times. On the one hand, KNU has lost the people's strong support in the region since from fifteen years ago because of the separation of the rival Democratic Karen Buddhist Army (DKBA). As the military cooperated with DKBA for counter-insurgency operations, $\mathrm{KNU}$ had to give up some of their bases in the border area with Thailand. Meanwhile, KNU also counterattacked to the military in terms of using guerrillas (McCartan, 2009).

Due to the conflicts and pressure under the military regime, many ethnic regions suffered the trauma conflicts and the number of refugees who fled to the neighbouring countries such as Thailand, China and India reached to the 200,000 . The ethnic people have always thought that peaceful coexistence is just a dream because of those military operations by the government (Chrisitina, 2000). The most influential and powerful groups, KNU suggested to proceed "united front" strategies in order to go against military government, SPDC's political policies. On the other hand, some ethnic leaders still had faith in new election and governing system which is a better way for democracy (Nederland, 2010).

\subsection{Myanmar with Its Ethnic Conflict in Current Situation (from 2011 to Present)}

After the 2010 national election based on the 2008 constitution, the democratic government was formed and the country's name has become "Republic of the Union of Myanmar". According to the new constitution, the political powers and administrative functions are divided into seven states, seven regions and one union territory which is also the capital city of the country under a bicameral legislature. Every citizen has rights to give three votes-one for each of the two parliaments and one for the region/state legislature. Unlike other administrative system, there are 6 new "self-administrative" region which are Danu, Kokang, Naga, Palaung, Pao and Wa. In 2010 election, Union Solidarity and Development Party won and formed the government which was headed by President $U$ Thein Sein (Smith, 2015).

During the new democratic government elected based on 2008 constitution, the President U Thein Sein and his ministers especially U Aung Min and U SoeThein decided to set up a new liberalization plan in politics. They met with 
the opposition leaders DawAung San Su Kyi and other political leaders in the country and also some ethnic political leaders. Moreover, the new government started calling for peace process on 18 August, 2011 in terms of maintaining long-lasting peace with ethnic armed groups. That announcement is the first official nationwide announced peace call in the country since after 1963. In discussion about peace, two teams were formed by the government named Team A and B. Team A was led by U TheinZaw, Central Executive Member of Union Solidarity and Development Party (USDP) which was also the ruling party at that time and U AungThaung, one of the patrons of the USDP. U Aung Min who was a Union Minister of the USDP government organized his group with some professionals from Myanmar Egress which is a non-governmental capacity building organization and think-tank. Team A discussed with United Wa State Army (UWSA), National Democratic Alliance Army (NDAA), The National Socialist Council of Nagaland (Khapalang) (NSCK-K), Shan State Progressive Party (SSPP), Democratic Karen Buddhist Army (DKBA), Peace Council, Kachin Independence Organization (KIO) and All Burma Student's Democratic Front (ABSDF) while Team B talked about peace with Karen National Union (KNU), Mon New State Party (MNSP), Restoration Council of the Shan State (RCSS), Karenni National Progressive Party (KNPP), Pa-Oh National Liberation Organization (PNLO), Chin National Front (CNF) and Arakan Liberation Party (ALP) in their beginning level (Oo, 2014).

RCSS and KNU singed the ceasefire agreement in December, 2011 and January, 2012 and those active participations of those two groups became the strong support to other groups for peace process. However, the ethnic armed organizations are still feeling distrust and doubt that the government has genuine mind on the peace process. Therefore, the government led by President $U$ Thein Sein created a pathway for ethnic groups to participate in political sector that had never existed in the history of Myanmar for fulfilling the need for a political solution to stop the conflicts (Oo, 2014).

Although there are so many discussions about peace and ceasefire between governments and ethnic armed organizations, many ethnic leaders themselves want ethnic armed groups which already agreed ceasefire with the government in the ethnic territories because they want to make sure to get the new political system in the region after the disarmament and reorganization of their civil administration negotiate with the government (Nederland, 2010). As U Thein Sein government tried so hard for peace process, Myanmar Peace Centre (MPC) was formed in October, 2012 in order to proceed more functions for peace as an effective communication tool. MPC is a hybrid organization recognized by the president but also as a non-governmental organization (NGO) supported by European Union for peace. MPC's organizing structure is quite significant that there are different sides which included people with various backgrounds. 13 ministers and senior officials participated in MPC as senior executives from government's side, meanwhile, many professionals who returned from over two 
decades of exile due to political issues and some who were ex-rebels. Those people worked from technical aspects of the peace process in MPC (Oo, 2014).

Myanmar's peace process has started from 2011 and currently the path is already being for 7 years. In the process, key ethnic armed organizations have participated and discussed about peace process and 8 ethnic organizations among them already signed the Nationwide Ceasefire Agreement (NCA) (Johanson, 2017). In other way, NCA can be regarded as the first achieved step for a nationwide peace process and formal Union political dialogue will be later followed. However, among the ethnic armed organizations, three influential groups such as Kachin Independence Army, the United Wa State Army and the Shan State Progressive Party/Shan State Army (SSPP/SSA) did not sign the NCA. There are questionable sometimes that when and how other Ethnic armed organizations are willingly to be involved in the political dialogue and sign the NCA in order to complete the aim of the peace process (The Peace Process, 2011 to 2015,2018 ).

The current NLD government is trying their best for negotiation and discussion about peace and is following the procedures what the previous government did in the peace process. One advantage of the current government is "Aung San Su Kyi" who is Nobel Prize winner for peace and also famous for her political status and international backing as the state counsellor of Myanmar (Crisis Group Asia Briefing No. 149, 2016). She and her government are supporting a lot for peace process as their first priority, however there are many complicated challenges, for example, there are still some ethnic armed organizations left for signing the ceasefire agreement and balancing the two sectors which are ceasefires monitoring and setting up political dialogue in parallel. Moreover, the procedure to build the trust between government and ethnic armed organization is significantly difficult tasks for completing (Swiss Peace, 2016).

Though she has been showing her strong support and belief for democratic country based on federalism, ethnic armed organizations are still having concerns about their political power and legitimacy. Basically, the NCA strongly expresses the most fundamental principles about the territorial integration of the state, accomplishing to set up the principles of democracy and federalism and understanding the diversity of ethnic people and their cultures within the state. For military, it is strongly prohibited to make attacks, reinforcement, recruitment, new bases, laying landmine and so on and it is supposed to deploy the troops in the regions. According to the principles, political dialogues must follow after the NCA which includes Union Peace Conference for supporting the peace agreement (Crisis Group Asia Briefing No. 149, 2016).

Throughout the history, it is clearly seen that the governments have been absent to implement the rights and opportunities for ethnic people. Mostly, they shaped the concept "nation-building" with the idea of "one religion, one language, one ethnicity" and moreover, the governments just tried to build an ethnically homogenous unitary state for majority Burmese people though the terri- 
tories of other ethnic minorities cover sixty percent of the total area of the country. Due to the suppression for many years, ethnic minorities have chosen the insurgency ways for their ethnic rights and preserving their ethnic culture and tradition which have been pressured for more than six decades. Moreover, such kind of civil war and armed conflicts support their ethno-nationalism as the driving force for their new types of politicized vernacular culture. Ethnic and political grievances are also the main factor of the conflicts in every governmental era.

Since from 2008, the new democratic government led by president $U$ Thein Sein initiated the new peace process by offering peace talks and negotiations to ethnic armed groups. Ethnic armed groups also willingly accepted for peace discussions and political talks. However, there are still occasionally some conflicts in some ethnic states between the ethnic armed groups and military while the government and representatives of ethnic armed organizations are discussing about peace. The following Table 1 shows the data about journey of the ethnic groups along the peace process during the military government before 2011 and the new democratic government after 2011 (Oo, 2014).

\section{Conclusion}

Some rural areas in Myanmar which are mostly ethnic populated have been affected by the conflicts between ethnic insurgent groups and military for more than half a century. For many decades, ethnic insurgents had controlled some ethnic boarder regions. The peace process currently underway in Myanmar represents the best opportunity in half a century to resolve ethnic conflicts in this troubled country. Nevertheless, the political, social and economic issues at the heart of the conflict will not be easily resolved. Due to addressing deep-rooted problems, both government and ethnic insurgents need to act with courage and imagination.

Table 1. Summarized information of ethnic armed groups which participated in the peace process before 2011 and after 2011.

Total number of armed groups that participated in ceasefire process during the military regime

The number of armed groups which disarmed or transformed into the People Militia before 2009 during military government

The number of armed groups which remain not to include in ceasefire process by 2009

Number of armed groups which disarmed and transformed into Border Guard Force (BGF) under military government

Number of ceasefire groups that transformed into People Militia

Number of ceasefire groups which refuse to join BGF and People Militia 
Charles and South (2012) also analyzed about the peace building process in Myanmar that a particularly significant, but largely unremarked, challenge lies in conceptualizing and working constructively on the relationship between government structures and those ethnic insurgent groups (Charles \& South, 2012). According to their analysis report, it is true that any armed opposition groups have long-established, if chronically under-resourced, para-government structures, especially in the educational, health and local administration sectors. So, deepening of the peace process should include participation of affected communities and other stakeholders, such as civil society and political actors, with special attention to the roles of women and young people.

Marte and Stein (2013) point out that there is a risk that Myanmar may experience a backlash in relation to the peace process if civil society and political parties are not included. If they do not feel a sense of ownership and participation, civil society and political actors, especially ethnic political parties and urban-based civil society, may begin to mobilize to demand their inclusion as stakeholders. They argued that ethnic political parties have played a minuscule role in the peace process throughout the times (Marte \& Stein, 2013). From the point of political view, the low levels of ethnic minority representation and marginalization on the ethnic people in the current political sector will surely continue to represent an obstacle for progress in this peacebuilding process era.

The ethnic conflicts in Myanmar are mainly based on the inequality and discrimination concerning ethnic rights and mostly, the conflicts are between the military and ethnic armed groups. However, since from 2011, the new democratic government has tried to shape the systematic and all-inclusive peace process and the nationwide ceasefire agreement could be implemented in 2015. On the other side of ceasefire agreement and peace process, some conflicts and clashes are still breaking out in some specific ethnic regions. There is also one more problem apart from the conflicts between government and ethnic armed organizations which are the conflicts between signatory to ceasefire groups and non-signatory to ceasefire groups due to the territorial disputes and political influences in the region. Among such kind of conflicts, the conflicts between Palaung State Liberation Front/ Ta'ang National Liberation Army (PSLF/TNLA) and the Restoration Council of Shan State/Shan State Army-South (RCSS/SSA-S) become the major problem because those conflicts lead to lack of security and stability in the region and more number of war victims and refugees in the region. The following Figure 1 shows the data about the number of battles between PSLF/TNLA and RCSS/SSA-S during the period from 2010-2018 (Bynum, 2018).

By looking through and analyzing the whole peace process of Myanmar from independence to current time, not only with the solution politically, Myanmar government should emphasize on education system in implementing peacebuilding process. However, the most difficult challenge is the imbalances in resources and teachers not only in formal government schools and also ethnic and community education system. On the other hand, Myanmar government should 


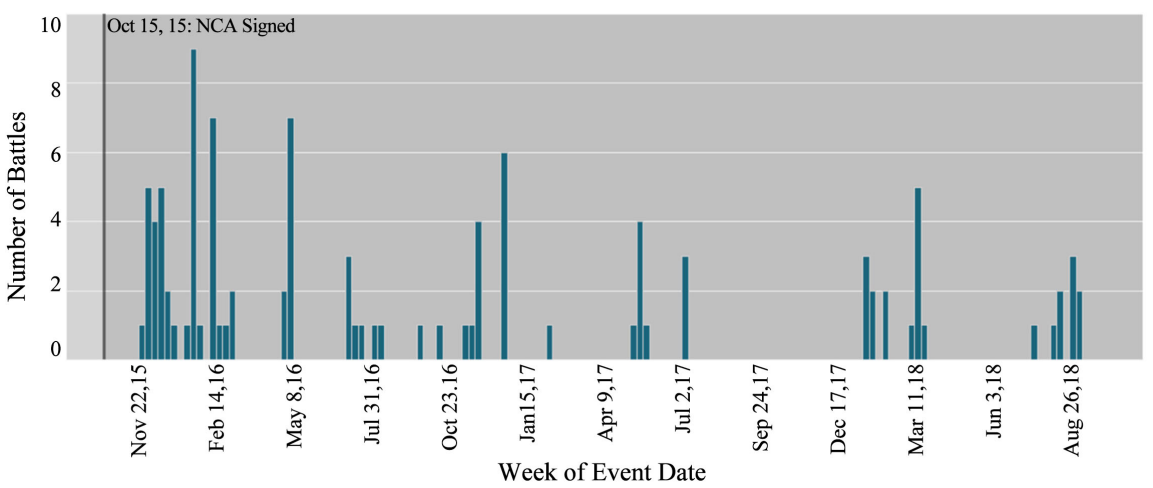

Figure 1. The number of battles between PSLF/TNLA and RCSS/SSA-S from 2010-2018, Bynum, 2018, retrieved from https://www.acleddata.com/2018/09/28/understanding-inter-ethnic-conflict-in-myanmar $\underline{1}$

promote the freedom of ethnic cultures and traditions and moreover ethnic rights in the country. Under the current situation, there is one Ministry for ethnic affairs and the law for ethnic people is already stated. However, such ministry and law are not effective that much in dealing with the real conflicts and situations in Myanmar. In conclusion, Myanmar needs only state-building of a decentralized federal union with open society where all different ethnic groups can promote and maintain their languages, literatures, customs and traditions and moreover, the better and effective communication tool is the most essential in curing the trauma of conflict resolution in Myanmar.

\section{Acknowledgements}

I would like to thank to all my professors and colleagues who always encourage me to carry out this research paper. Moreover, I would like to show my sincere gratitude to everyone who supports me getting the resources and ideas for this analysis paper.

\section{Conflicts of Interest}

The author declares no conflicts of interest regarding the publication of this paper.

\section{References}

Aslam, R. (2014). The Role of Media in Conflict: Integrating Peace Journalism in the Journalism Curriculum. Aukland, New Zealand: Pacific Media Centre, Aukland University of Technology.

Barash, D. P. (2000). Preventing War: Building Negative Peace. In D. P. Barash, Approaches to Peace: A Reader in Peace Studies (pp. 61-64). Oxford, UK: Oxford University Press.

Bonta, B. D. (1996). Conflict Resolution among Peace Societies: The Culture of Peacefulness. Journal of Peace Research, 33, 403-420.

https://doi.org/10.1177/0022343396033004003 
Bynum, E. (2018). Understanding Inter-Ethnic conflict in Myanmar. ACLED: Bringing Clarity to Crisis.

https://www.acleddata.com/2018/09/28/understanding-inter-ethnic-conflict-in-myanm $\underline{\mathrm{ar} /}$

Charles, P., \& South, A. (2012). Mapping of Myanmar Peacebuilding Society. European Commission.

Chrisitina, F. (2000). An Overview of Burma's Ethnic Politics. Cambridge, England, UK: Cultural Survival Quarterly Magazine.

Crisis Group Asia Briefing No. 149. (2016). Myanmar's Peace Process: Getting to a Political Dialogue. Yangon/Brussels: International Crisis Group.

Galtung, J. (1996). Peace by Peaceful Means: Peace and Conflict, Development and Civilization. London, UK: Sage Publications Ltd.

Galtung, J. (1998). High Road, Low Road-Charting the Road for Peace Journalism. Centre for Conflict Resolution. South Africa: Centre for Conflict Resolution.

Galtung, J. (2010). Peace Studies and Conflict Resolution: The Need for Transdisciplinarity. Transcultural Psychiatry, 47, 20-32. https://doi.org/10.1177/1363461510362041

Gellener, E. (1983). Nations and Nationalism. New York: Cornell University Press.

Gravers, M. (1993). Nationalism as Political Paranoia in Burma: An Essay on the Historical Practice of Power. Copenhagen: NIAS.

Horowitz, D. L. (1985). Racial Violence in the United States. In K. Glazer, \& K. Young, Ethnic Pluralism and Public Policy (pp. 8-30). London: Lexington Books.

Johanson, V. (2017). Creating an Inclusive Burmese Peace Process. Peace Brief. United States Institute of Peace.

Lederach, J. P. (1995). Preparing for Peace Conflict Transformation across Cultures. Syracuse, NY: Syracuse University Press.

Lijphart, A. (1969). The Politics of Accommodation. Los Angeles, CA: University of California Press.

Lintner, B. (1999). Burma in Revolt. Chaing Mai: Silkworm Books.

Marte, N., \& Stein, T. (2013). Political Parties and Peace Building in Myanmar. Oslo: Peace Research Institute.

McCartan, B. (2009). Victoryover KNU, New Orderon Thai-Burma Border. Yangon: Mizzima.

Mitchell, C. (1981). The Structure of International Conflict. London: McMillan.

Nederland, B. C. (2010). Ethnic Politics in Burma: The Time for Solutions. Amsterdam: Transnational Institute.

Oo, M. Z. (2014). Understanding Myanmar's Peace Process: Ceasefire Agreements. Yangon: Swiss Peace.

Peleg, S. (1999). Who Participates in Protracted Conflicts and Why? Rediscovering the Group and Its Needs. In H. Starr (Ed.), The Understanding and Management of Global Violence (pp. 105-130). New York: Martin's Press.

Power, S. (2002). “A Problem from Hell”: America and the Age of Genocide. New York: Basic Books.

Sakhong, L. H. (2010). In Defence of Identity: Ethnic Nationalities' Struggle for Democracy, Human Rights and Federalism in Burma. Bangkok: Orchid Press.

Sakhong, L. H. (2012). The Dynamics of Sixty Years of Ethnic Armed Conflict in Burma. Yangon: Burma Centre for Ethnic Studies, Peace and Reconciliation. 
Schein, J. K. (2013). Ethnofederalism and the Accomodation of the Ethnic Minorities in Burma: United They Stand. Monterey, CA: Naval Postgraduate School.

Silverstein, J. (1977). Burma: Military Rule and the Politics of Stagnation. London: Cornell University Press.

Silverstein, J. (1981). Military Rule in Burma since 1962. Singapore: Lehman.

Silverstein, J. (1993). The Political Legacy of Aung San. New York: Cornell University Press.

Smith, M. (2007). State of Strife: The Dynamics of Ethnic Conflict in Burma. Washington DC: East-West Centre Press. https://doi.org/10.1355/9789812304803

Smith, M. (2015). Ethnic Politics in Myanmar: A Year of Tension and Anticipation. Southeast Asian Affairs, 48, 214-234.

Smith, M., \& Ekeh, C. (2007). Minorities in Burma. London: Minority Rights Group International.

Spiller, P. (2002). Dispute Resolution in New Zealand. Oxford: Oxford University Press.

Swiss Peace (2016). Perspectives on the Myanmar Peace Process 2011-2015. Yangon: Swiss Peace.

Taylor, R. (2009). The State in Myanmar. Singapore: NUS Press.

Taylor, R. (2017). Myanmar's Military and the Dilemma of Federalism. SEAS Visiting Senior Fellow. Singapore: Yusof Ishak Institute.

The Peace Process 2011 to 2015 (2018). Alliances for Gender Inclusion in Peace Process. https://www.agipp.org/en/peace-process-2011-2015

Tinker, H. (1967). The Union of Burma: A Study of the First Years of Independence. London: Oxford University Press.

Tucker, S. (2001). Burma: The Curse of Independence (pp. 8-9).

Varshney, A. (2009). Ethnicity and Ethnic Conflict. The Oxford Handbook of Comparative Politics, London: Oxford University Press. 